\title{
RISE OF THE PANDEMIC (COVID-19) AND SECURITY OF THE INSIDERS: A NEW CHALLENGE FOR TRADITIONAL BORDER POLICIES IN THE EU
}

\author{
Zuhal KARAKOÇ DORA* \\ Araştırma Makalesi
}

\begin{abstract}
Borders not only determine where the territories start and end; but also determine the insiders and the outsiders while regulating entrances and exits. Last century was of great importance in transformation of security and border issues. However, for two decades, sharp changes started to turn up due to evolving challenges that we face. After migration crisis, arising from the ongoing civil war in Syria, the biggest challenge the world, notably the EU, has faced is the COVID-19 pandemic which carried the border security issue to a new dimension that never came to mind. Today's border security policies are built on protecting citizens from microorganisms, viruses and carriers and it seems that "others" will continue to be both at the centre and out of these policies.
\end{abstract}

Keywords: Border, Security, the EU, Migration, COVID-19.

\section{Pandemi (COVID-19) ve İçeridekilerin Güvenliği: Avrupa Birliği’nin Geleneksel Sınır Politikalarına Yeni Yaklaşımı}

$\ddot{O} z$

Sınırlar yalnızca toprakların nerede başlayıp nerede bittiğini belirlemez, aynı zamanda giriş ve çıkışları düzenlerken içeridekilerle dişarıdakileri de tanımlar. Geçtiğimiz yüzyıl, güvenlik ve sınır sorunlarının dönüşümü açısından oldukça önemlidir. Bununla birlikte son yirmi yılda ortaya çıkan yeni gelişmeler, sert değişimleri de beraberinde getirmiştir. Suriye'de devam eden iç savaştan

* Dr., Türkiye Büyük Millet Meclisi, E-Posta: zuhal.dora@yahoo.com, ORCID: 0000-00023954-2208.

Makalenin Gönderilme Tarihi: 20/09/2021 Kabul Edilme Tarihi: 22/11/2021 
kaynaklanan gö̧ krizinin ardından başta AB olmak üzere dünyanın karşılaştığı en büyük zorluk, slnır güvenliği konusunu daha önce hiç akla hiç gelmeyen yeni bir boyuta taşıyan COVID-19 salgını olmuştur. Bugünün sınır güvenliği politikaları vatandaşları mikroorganizmalardan, virüslerden ve taşlylcılardan korumak üzerine inşa edilmiş durumdadır ve bu politikaların hem merkezinde hem de dişında ise "ötekiler" bulunmaktadır.

Anahtar Sözcükler: Sinır, Güvenlik, AB, Göç, COVID-19.

\section{Introduction}

The history of human being is mostly a history of wars, and the eventual purpose of nearly all these wars was the changing of borders. ${ }^{1}$ Borders, which are fundamental both for the security of the nation states and their people, are built on the idea of security. According to Maslow's hierarchy of needs pyramid, security issue becomes just after the basic physiological needs of human being. ${ }^{2}$ After guaranteeing these basic needs, such as food, water and shelter, human being progressively search for securing these acquisitions in order to be able to level up through following steps. In this respect, it is possible to claim that without establishing security, it is impossible for people to protect what is in their hands and to develop in other means. The underlying reason why states emerged lies behind this fact.

Especially after the Peace of Westphalia, when the nation states and borders become more important, security concept started to dominate world politics. The First World War, after which League of Nations was founded to establish collective security; the Second World War, which showed League of Nations did not run well; the Cold War, after which human security issues became forefront all proved that security issue could not be imagined in just one dimension. Ranging from hunger to natural disasters, diseases, climate change, migration flows, regional conflicts, civil wars, genocide, terrorism and nuclear weapons; the issue of security is a complex, dynamic and multidimensional area.

Throughout history, border security policies have been implemented in different ways and according to the changing threats. As the fear of threat

1 Sergei V. Sevastianov et al., Introduction to Border Studies, (Vladivostok: Dalnauka, 2015), 33.

2 Abraham H. Maslow, “A Theory of Human Motivation”, Physiological Review, Volume 50, No 4 (1943): 370-396. 
has a continually changing character, these policies have also evolved in parallel with the perception of threats. Yet, protecting the indoors remained as the unc0hanged object of these policies. Thus, "others", whether they are invaders or migrants, have always been the ones to be kept out. While migrants have been welcomed from time to time as they might contribute to the economy (or army in the past periods); they are generally perceived as the ones who decrease the level of common wealth unless they are tax payers. Though human mobility has been one of the prime issues on the states' agendas since the Cold War, it reached its peak after the Syrian crisis that outbroke in 2011. At the beginning of the last quarter of 2015, monthly number of the refugees trying to enter Europe was 218.394 equivalent to the total number that entered during the whole of 2014 , and more than $50 \%$ of these were Syrians. ${ }^{3}$ With thousands of irregular migrants accumulated at the borderlines of the EU, border policies, inevitably, started to occupy the agendas of the governments.

Since the eighteenth century, when Adam Smith stipulated the rules of economic liberalism in The Wealth of Nations, the thought of free trade has started to dominate international relations. ${ }^{4}$ Indeed, it was the fundamental ground of the EU, which was simply based on the idea of free trade and followed by the Schengen Code (1985) for free movement (internally). The most successful example of the elimination of the borders between countries without undermining sovereign rights is the European Union Community established with the Treaty of Rome. By removing the borders, the EU managed to bring the multiplier effect of the economy to an extraordinary dimension and to establish peace through economic dependency.

However; the main principles of the EU expanded in time, concurrently with territorial expansion. Especially with the migration crisis, it became apparent that the EU was not a steady block; rather it was composed of different states despite the borderlessness fact. The EU plan, which determined the burden sharing on refugees with the Dublin Convention, could be claimed to be damaged in 2015-2016. Germany and Hungary stated

3 Tom Miles and Depetris Mariana, “October's Migrant, Refugee Flow to Europe Roughly Matched Whole of 2014." Reuters UK, November 2, 2015, Accessed: July 30, 2021, https://www.reuters.com/article/us-europe-migrants-un/octobers-migrant-refugee-flow-toeurope-roughly-matched-whole-of-2014-idUSKCNOSR15P20151102.

4 James F. Hollifield, “The Emerging Migration State", The International Migration Review, Volume 38, No 3 (2004): 886. 
that they suspended the Dublin Convention for the refugees coming from Syria $^{5}$ which was followed by other countries soon. The suspension of Dublin Convention would mean that Schengen System was punctured, yet it was due to the fact that migration issue was mostly seen as a security issue threatening the nation states, the economies and the citizens. ${ }^{6}$

While the migration flow issue has not yet been solved within and beyond the EU, another wave of crisis emerged worldwide. A new kind of Coronavirus, called COVID-19, outbroke in China towards the end of 2019 and extended rapidly all around the world, turned into a pandemic. Italy was the first EU country who became the centre of the virus in the world having the biggest number of infected people and greatest death rate. The EU's first border problem during this period was between Italy and Austria. Austria denied the entry of a train from Italy, where the virus was most common, into its country. This situation spread to all countries in a short time and the legendary common border policy of the EU seemed to take a new form. Soon, the Schengen Borders Code provided member countries with the potential re-establishing of checkpoints at the interior borders on an interim basis in case of an acute threat to public policy or internal security. ${ }^{7}$ The reinstatement of internal border checkpoints led to a great transformation in the security and border policies. For the EU, which tries to solve the migrant crisis by strengthening the borders and keeping the migrants in the territory of Turkey like a buffer zone, this pandemic has provided an opportunity to make its border policies even more strict using security discourses. After the pandemic, EU confirmed that current system of borders no longer work and proposed a new Pact on Migration and Asylum covering each of the elements needed for a more comprehensive European approach to migration and setting the principles of fair sharing of responsibility and solidarity. ${ }^{8}$ However; the Pact was problematic in many aspects as border security was

5 Adem Akkaya, “Almanya'nın Zorunlu Tercihi: Mülteci Krizi Ekseninde Türk-Alman Ilişkilerini Yeniden Düşünmek”, Regional Studies, Volume 1, No 1 (2016): 26.

6, Ina Lodewyckx et al., "From Nation State to Migration State", Economics and Sociology, Volume 3, No 2, 2010.

7 Council of the European Union, "Temporary Reintroduction of Border Control." Accessed: August 10, 2021, https://ec.europa.eu/home-affairs/what-we-do/policies/borders-and-visas/ schengen/reintroduction-border-control_en

8 Council of the European Union. "A Fresh Start on Migration: Building Confidence and Striking a New Balance Between Responsibility and Solidarity." Accessed: August 30, 2021, ec.europa.eu/commission/presscorner/detail/en/ip_20_1706 
once again prioritized in the Pact and protecting the EU's borders was highlighted besides allowing member states to opt out from participating in the relocation of asylum seekers and refugees within the EU. ${ }^{9}$

In this paper, while analysing the security concept; the historical process and driving forces of border policy implementations are examined concurrently with the migration policies of the EU. This paper seeks to associate the process of border policies and security perceptions with newlyemerged COVID-19 pandemic. Today's brand-new border security perception is built upon protecting the people of the country from microorganisms, viruses and carriers. This new version of border security, which seems to be obvious for a long time, continues on two main lines first of which requires absolute international cooperation and second of which is the absolute isolation of each country, closing its borders to all kinds of entrances.

\section{Why Border Security and What Do Borders Protect: the State or the People?}

Security studies have highly remained under hard suppression of traditionalist approach which was led by realist view until the end of the Cold War in which the main actor was the "state" and the military tools were the main instruments of the instalment of security. ${ }^{10}$ According to Walt, a traditionalist in security studies, the main concern of security analysis was war and the ways of using force were naturally affecting the states and societies. ${ }^{11}$ Baldwin was the first during traditional period of security studies who systematically described security by answering these questions: security for who and for what values, against which threats, with what tools, at what cost, how long and to what extent. ${ }^{12}$ The answer to these questions was revolving around the realist approach. But with the end of the Cold War,

9 Kemal Kirişçi et al., "The EU's New Pact on Migration and Asylum" is Missing a True Foundation." 6 November 2020, Accessed: August 30, 2021, https://www.brookings.edu/ blog/order-from-chaos/2020/11/06/the-eus-new-pact-on-migration-and-asylum-is-missinga-true-foundation/

10 Mustafa Aydın et al. Strateji ve Güvenlik, (Eskişehir: Açıköğretim Fakültesi Yayınları, 2012).

11 Stephen M. Walt, “The Renaissance of Security Studies”. International Studies Quarterly, Volume 35, No 2 (1991): 211-229.

12 David Baldwin, "The Concept of Security", Review of International Studies, Volume 23, No 1 (1997): 23. 
besides many perceptions, the security studies started to transform as well under the leadership of Barry Buzan and Richard Ullman. According to Buzan, one of the leading theorists of Copenhagen School, the security should not be limited to military area and could be categorized in five main sectors like economic, political, social and environmental, including military ones. ${ }^{13}$ As the actors are not limited and could be extended from states to non-governmental organizations, terrorist organisations and/or multinational companies; the threat itself is also varied and not limited to military threats. And for Ullman, one of the advocates of the extended security approach, security threats are threats that reduce the quality of life of the citizens of a country or narrow the policy preferences of private, non-state actors (individuals, groups, companies) and governments in a country. ${ }^{14}$ As this is the case, while it is possible to define what the concepts of security and threat might include or exclude, today -with the rise of extended security approach- there is not a shared and commonly agreed-on definition that fulfil these concepts; what might constitute a security threat to one country might not constitute the same threat for another due to the subjective nature of fear. ${ }^{15}$

After transformation and extension of the security area and with the increase and variation of threats and fears, many new security establishment tools have also been added to the stage. Now then, hard or soft security discourse used in the aftermath of the Cold War period, has been a subject of hot debate for the politics and international relations, and naturally for the field of migration. ${ }^{16}$ Despite all these diversities in the perception of concept of security, the fear and threat mostly remained same and it has not evolved into a situation that is very different from traditional approach. "Others" still play the main role in causing fear and one of the most effective methods of overcoming this fear still lies in establishing border security.

13 Barry Buzan, People, States and Fear: An Agenda for International Security Studies in the Post-Cold War. (London: Pearson Longman, 1991), 5.

14 Richard H Ullman, "Redefining Security”, International Security, Volume 8, No 1 (1983): 129-153.

15 Zuhal Karakoç Dora, "Borders, Terror and Immigration: the ISIS Case", Hasan Acar and Halil Emre Deniş (Eds.), Security Issues in the Context of Political Violence and Terrorism of the $21^{\text {st }}$ Century. (New Castle: Cambridge Scholars Publishing, 2021), 144.

16 M. Murat Erdoğan, "Securitization from Society and Social Acceptance: Political PartyBased Approaches in Turkey to Syrian Refugees", UI Dergisi, Volume 17, No 68 (2020): 73-92. 
Border security practices have always been entangled, embedded but also impugned not only by those who cross the borders, but also by those who manage them. ${ }^{17}$ Though border security policies are driven by subjective threats, rather than objective ones, common thread to all these policies are the aim of protection. Politics compels making tough preferences on priorities and on the expenses of public resources; thus, how to grant scarce funds for martial readiness in contrast with meeting the requirements of its own people and ensuring them secure and long lives, is a significant disputation for all states. ${ }^{18}$ Although both of the options handle and focus on the security issue, the ultimate aim of what they primarily prefer to preserve is different. While the former category looks to arms to combat threats and preserve national security, the latter stresses human security that places an emphasis on protecting the well-being of individuals, neither of which can be tracked down without making sacrifice for the other. ${ }^{19}$

Though the idea that borders are the barriers for protection is commonly shared, what they are supposed to protect primarily is an area of conflict by the scholars. One prominent apologia for securing the border starts with the idea that every country has its own specific nationwide character, and that the country's borders safeguard it from being submerged by outlanders as the country is not just a state, but a cultural or ethnic nation which is to be ensured that migration does not disturb that composition. ${ }^{20}$ The state itself, here, is predominantly to be protected from the "outsiders", or "others". Another one is that the state and its institutions are rightfully possessed by those who have worked to build and sustain those institutions; therefore, they have the right to reject the idea of sharing their institutions with the others. ${ }^{21}$ Here, the insiders and their prosperity are supposed to be protected essentially as they are the owners and ones who make the state a state. Regardless of whichever comes first, the main idea remains in both cases: borders are for the "others". Though the definition of others and how to call

17 Karine Cote-Baucher et al., "Border security as practice: An agenda for research", Security Dialogue, Volume 45 (2014): 198.

18 Shannon Lindsey Blanton and Charles William Kegley, World Politics: Trend and Transformation. (Wadsworth: Cengage Learning, Boston, 2016-2017), 152.

19 Ibid. p.152.

20 Michael Blake, "What Exactly Is the Point of the Border?" 25 July 2018, Accessed: August 12, 2021, https://theconversation.com/what-exactly-is-the-point-of-the-border-99990 21 Ibid. 
them (enemies, invaders, intruders, outsiders, migrants etc.) change from case to case since the beginning of history; the reaction of the communities and the state they found has remained more or less the same: keeping them away unless they are useful.

In recent years, border security policies have appeared to be on the upswing especially after the upheavals in the Middle East region. When internal conflict in Syria turned into a civil war and proxy wars began within the borders of Syria soon after the war erupted, the effects of the war refugee crisis- concurrently appeared both in neighbouring states like Turkey and in Europe. European countries primarily preferred to strengthen their borders with the purpose of dealing with irregular migration and keeping the refugees beyond their borders and secondly sought to shift the problem outside of European boundaries by building buffer zones. ${ }^{22}$ Since the EUTurkey relations after the refugee crisis almost entirely rest on the refugee crisis, which loads shield mission to Turkey, explains this situation best. In a few years of mass migration flows to Europe, for the sake of the security of the EU states and its citizens against this threat, traditional methods of border security policies were put into practice: the erection of the walls and barbed wires. ${ }^{23}$

When compared to EU's previous experience of migration, this latest wave has put a fragile effect on its security policies. Because during the Cold War, when figurative curtains, real bullets and barbed wire facilitate to limit grand scale mobility from East to West, Western governments relatively well-operated the refugee system, which means they led to only few political problems. ${ }^{24}$ Due to their limited numbers and similar cultural backgrounds these migrants did not cause great fears or reactions in the West. But the

22 M. Murat Erdoğan, "Açık Kapı Politikasından Açık Sınır Politikasına Türkiye'deki Suriyeliler", 9 March 2020, Accessed: August 29, 2021, https://www.uikpanorama.com/ blog/2020/03/09/acik-kapi-politikasindan-acik-sinir-politikasina-turkiyedeki-suriyelilermurat-erdogan/

23 See Jernej Zupancic, "The European Refugee and Migrant Crisis and Slovenian Response", European Journal of Geopolitics, Volume 4, 2016, p. 95-121; Shara Tibken and Joan E. Solsman. "For Refugees on Hungary's Border, Razor Wire Trumps Tech", https://www.cnet.com/news/for-refugees-on-hungary-serbia-border-razor-fence-wiretrumps-tech/ and IOM, International Organization for Migration. "Compilation of Available Data and Information", https://www.iom.int/sites/default/files/situation_reports/ file/Mixed-Flows-Mediterranean-and-Beyond-Compilation-Overview-2015.pdf.

24 Gil Loescher, The UNHCR and World Politics: A Perilous Path. (Oxford: Oxford University Press, 2001), 54-57. 
process of great influx of migration during the last decade, arising mostly from the Middle East and Africa due to internal conflicts or lack of sources and reaching its peak after Syrian crisis, completely started to change the border policies of the target countries, notably the EU. Borders were thickened and a collective approach throughout the EU were tried to be established although there were disapprovals and objections to some points and heavy debates within the outer borders of the Union.

While migration was playing the basic role in this change, another challenge arouse unexpectedly. Albeit the control of the outer borders had not fully been managed against the uncontrolled human mobility influx threat yet, a new threat started to hit the internal borders of the EU. As the virus outbroke in Europe, member states such as Germany and France took measures primarily on the basis of national borders regarding their own security which stresses the fact that even if nations are in a supranational structure like the EU, they will look after their own national borders/interests rather than the borders of the Union in the face of the immediate security threats they will face. ${ }^{25}$ The pandemic of COVID-19 emerged as a cork jacket for those who are in favour of firmly restricting the entries and exits through borders. Before going through the COVID-19 pandemic, it would be better to have a look at the historical background of the EU and the policy of borderlessness.

\section{A. Borderlessness: EU Case}

With reference to speeding up of the emerging patterns of financial, civic and cultural globalization during 1970s and 1980s, scholars focused on debates over "a borderless world" of which the core agenda revolved around globalization theories. ${ }^{26}$ However, when we look at the history of the EU, we see that the roots of borderlessness date back further. In the aftermath of the Westphalian Peace Treaty of 1648, the sovereign states and their borders became determinants of the world order. Since then, securing the borders and the insiders have been of great importance in establishing the national security and thus, "nation" and the "others" have become major centres of

25 Ertuğrul Urker, "COVID-19: The Virus Crossing Borders", 16 April 2020, Accessed: August 25, 2021, https://www.internationalaffairshouse.org/covid-19-the-virus-crossingborders/

26 Liam O'Dowd, "From a 'Borderless World' to a 'World of Borders: Bringing History Back In”, Society and Space, Volume 28 (2010): 1031-1050. 
attention addressing security policies. ${ }^{27}$ Although the main priority of each country is to protect its borders, it has been witnessed frequently for some powerful countries not only to protect their borders, but also to expand the borders with different motivations which has been the reason for many wars. While one indispensable part of history is the war, building not only powerful armies but also unions to avoid war has been another part. The unions have brought more than one state together to protect common interests against common enemies, gaining greater benefits if possible. The effort of states that are tired of wars and exhausted both human capacities and assets to become unified and fight against "real enemies", or sometimes against fictional ones, especially with religious motivations, is an important part of the history of Europe. ${ }^{28}$

Undoubtedly, the most important factors in questioning the borders in Europe, which entered into the process of nationalization with Westphalia, are the French Revolution attained with the motto of "equality, freedom, brotherhood" and the industrialization revolution that created a new socioeconomic world. In particular, the economic transformation in Europe has caused emotional barriers to be questioned and borders to be discussed. After the 18th century, although the states strictly protect their political boundaries, the free movement of economic borders and especially products has become the existential aim of the capitalist order. For this reason, many efforts have been made to eliminate the economic borders between countries without harming the rights of political sovereignty. These efforts have always had not only economic but also philosophical, moral and emotional backgrounds. In the idea of unity in Europe, the proposal of "European Integration" mentioned by Immanuel Kant (1724-1804) in his work "Perpetual Peace" has an important place. Kant puts the Union in question on an ideological basis and says, "Only states whose internal governance is based on people's sovereignty will/can be a member of this (European) federation!". ${ }^{29}$ It is no coincidence that these words are similar to the principles of the EU, which were determined in 1993 and called the

27 Zuhal Karakoç Dora, "International Migrants as a Matter of Security: Open Door Policy and Syrians in Turkey”, Güvenlik Bilimleri Dergisi, Volume 9, No 2 (2020): 501-524.

28 Christopher Brooks, Western Civilization: A Concise History Volume 3: Religious Wars, Accessed: August 14, 2021, https://pressbooks.nscc.ca/worldhistory/front-matter/174/

29 Immanuel Kant, "Perpetual Peace", Reiss, H. (Ed.), Kant's Political Writings. (Cambridge: Cambridge University Press, 1970), 104. 
Copenhagen Criteria. Kant put forward the philosophy of unification two hundred years before the EU. Similarly, Victor Hugo would say;

"The day will come when you-France, Russia, Italy, England, Germany, you all the Nations of the Continent-will meet to form a higher union without losing your distinctive quality and your individual characteristics. You will create the brotherhood of Europe... The day will come when there will be no other battlefield than the market open to business and brains open to ideas. The day will come when bullets and bombs will be replaced by ballot paper, by universal right to vote, by arbitrages of a sovereign Senate..."

during Peace Congress in Paris in $1849 .{ }^{30}$ Roughly in the same period, Ricardo's "Comparative Advantage-Interest Theory" or the theories of Mill, Bright, Cobden that talk about the peace-making role of economic integration took an important role in development of the idea as well. ${ }^{31}$

World War I has a special place in the context of borders and states. On the one hand, this war put an end to the giant empires of Europe, thus revealing many nation-states, each of which tried to protect their borders. But, on the other hand, this war, with the effect of the strengthening of the military equipment used, also revealed how consuming and destructive the war is both in human and economic terms. The economic union named BLEU, which was formed by Belgium and Luxembourg in 1921 right after the war, opened an important door in the new world where nation states were the main actors, showing that "borders" were not always good in all matters. With the inclusion of the Netherlands, this small trial produced a model in 1944 with the decision to mutually remove the borders of these three countries. Moreover, these efforts arouse in the tense environment of the next great war. The BENELUX model would inspire efforts after the second

30 Victor Hugo, "Speech of Victor Hugo to the Peace Congress at Paris". The Sydney Morning Herald, December, 26, 1849.

31 See John Stuart Mill, Principles of Political Economy with Some of Their Applications to Social Philosophy, $1^{\text {st }}$ Ed, London, John W. Parker, 1848; David Ricardo, On the Principles of Political Economy and Taxation, London, John Murray 1817; Bill Cash, John Bright: Statesman, Orator, Agitator, New York, I. B. Tauris \& Co Ltd., 2012 and Nicholas C. Edsall, Richard Cobden: Independent Radical, Boston, Harvard University Press, 2014. 
major war. With the effect of the great devastation after World War II and with the idea of "establishing peace and creating economic cooperation and even dependence to increase prosperity", the BENELUX countries, which have already established a system between themselves, Germany, France and Italy initiated a historical transformation by agreeing upon the establishment of European Coal and Steel Community in $1951 .{ }^{32}$ The process, which took a very important step with the Rome Treaty in 1957, formed a system which was first called the EEC, then the EC and later the EU. It succeeded in removing the borders and pulling the multiplier effect of the economy to an extraordinary extent and establishing peace through economic dependence. EEC, EC and EU were projects of peace. In this context, a unique structure and success has been achieved in the world. In fact, the EU, which received the Nobel Peace Prize in 2012, proceeded to establish unity with its enlargement and deepening policies. Established with 6 member countries in 1957, the EEC reached 12 in 1990 and 28 member states with the membership of Croatia in 2017. The biggest success of the EU was to eliminate military conflicts between member countries and to direct the resources which were once transferred to war; to infrastructure, education and development. Despite all its shortcomings, the EU managed to become a unique union in the world by outreaching to use a single currency instead of national currencies and to turn borders into common borders. The EU, which opened its economic and social boundaries to each other and became stronger and richer with this, brought peace and prosperity to its member countries. ${ }^{33}$ Although the EU is still not a full political union, it is undoubtedly an important attempt to become a political union with its own flag, money and borders. It is known that the EU, which is the most successful peace and economic integration project in the history of the world, has many problems within itself and it has to go a long way towards becoming a full integration. An important part of the discussions is about whether the EU should be an economic union or a political union. The process of leaving the EU (Brexit) of the United Kingdom, who was the strongest advocate of the proposal for an economic union rather than a political one, cannot be considered separately from these discussions.

32 United Nations, "Post-war Reconstruction and Development in the Golden Age of Capitalism", World Economic and Social Survey 2017, Accessed: August 17, 2021, https://www.un.org/development/desa/dpad/wp-content/uploads/sites/45/WESS_2017_ch2.pdf 33 Ibid. 
Although it is difficult to predict where the future of the EU will evolve, it is clear that the EU experience is very instructive.

\section{B. Schengen and FRONTEX}

As in the case of the EU, each integration removes the borders within itself and paradoxically strengthens its borders against the outsiders. Sometimes even the condition of removing the borders inside may be protectionism against the others. In this context, the Schengen Agreement, led by Germany and France, was signed on June 14, 1985, covering the gradual abolition of internal borders between countries and the expanded control of external borders. The agreement signed by France, Germany, Belgium, Luxembourg and the Netherlands, which were 5 members of the EC, which had 10 members at the said date, was later accepted by many EU member countries.

The Schengen Area, whose membership and scope is expanding with each passing year, has ensured the abolition of land and sea controls between member countries as of December 2007 and airport and border controls in March 2008. With the help of SIS (Schengen Common Information System), which is liberating for "EU Citizens" but increasing the restrictions for the citizens of non-EU countries, the EU protects not only individual countries but the whole EU from "unwanted foreigners". It has also developed another strengthened control mechanism with FRONTEX. The duties of the European Border and Coast Guard Agency (FRONTEX) launched by the EU in 2004 and headquartered in Warsaw, the capital of Poland, are defined as follows:

- cooperation among member countries in the management of exterior borders,

- supporting member countries in training of national frontier guards,

- implementing risk assessment,

- complying research relevant for the management and supervision of exterior borders,

- supporting technical and operational assistance at exterior borders, 
- providing essential assistance in coordinating joint return operations. ${ }^{34}$

FRONTEX, which had 45 staff in 2005 and a budget of 5.5 million Euros, increased the number of staff to 750 in 2019 and its budget to 333 billion Euros. ${ }^{35}$ There is no doubt that the influx of refugees to Greece via Turkey after 2014 was the most important factor in strengthening the FRONTEX which is actively involved in the Aegean Sea and it has been assigned to protect the Bulgaria-Turkey external borders officially on behalf of the EU as of October 6, 2016. ${ }^{36}$

\section{Syrian Refugee Crisis, EU Borders and Turkey}

EU's one of the most important common foreign and security policy area is, beyond any doubt, Turkey. Though not being a member, as conducting membership negotiations with the EU, a member of NATO and an integral part of the EU's security policy, Turkey is coterminous with Greece and Bulgaria who constitute the EU's eastern border. After Turkey officially became an EU candidate country in December 1999, it was stated in the Accession Partnership Document of 2001 that one of the most outstanding issues in Turkey's accession process would be the issue of border security. If Turkey became an EU member, on which accession talks had already started on October 3, 2005, the external borders of the EU would be Turkey's southern, eastern and northern borders. For this reason, Accession Partnership Document of 2001, extremely important issues were mentioned under the titles of "judicial cooperation" and "strengthening administrative and judicial capacity":

- Adoption of the EU acquis in the field of data protection to participate in the Schengen Information System and Europol,

- Initiation of alignment of visa legislation and practices with those of the EU,

34 Council of the European Union, "Council Regulation (EC) nO:2007/2004" 26 October 2004, Accessed: September 13, 2021, https://eur-lex.europa.eu/eli/reg/2004/2007/oj

35 FRONTEX, "Key Facts”, 2021, Accessed: September 11, 2021, https://frontex.europa.eu/ faq/key-facts/

36 FRONTEX, "Origin and Tasks", 2021, Accessed: September 11, 2021, https://frontex.europa.eu/about-frontex/our-mission/ 
- Adoption and implementation of EU Legislation and practices on immigration (admission, readmission, deportation) to prevent illegal immigration,

- Start strengthening the border management and prepare for the full implementation of the Schengen Convention,

- Lifting the geographical reservation for the 1951 Geneva Convention in the field of asylum and developing residential and social support units for refugees,

- Complete public administration modernization reform to ensure effective implementation of EC policies, including strengthening border management and preparation for full implementation of the Schengen Agreement. ${ }^{37}$

This border security situation, the scope of which has been stated before, has found its practical importance and application with the Syrian refugee crisis. As known, the demonstrations that started in Tunisia at the end of 2010 turned into anti-regime actions in the region and spread to other Arab countries in a short time. The demonstrations became known as the "Arab Spring", also leaped to Syria in early 2011, but due to the disproportionate use of force by the current political authority against the demonstrators, it soon turned into large-scale conflicts and then into a civil war. Conflicts, which European countries preferred to remain silent at first, turned into a large-scale crisis, as new terrorist organizations, which took advantage of the vacuum of political authority, began to rapidly emerge and gain power in the region. Civil war, which have gone beyond being a regional internal conflict with the involvement of international actors turned into an international issue and Syria became the source of largest mass migrations the world has ever seen. The crisis left 6,7 million Syrians internally displaced and 6,6 million refugees of whom 5,6 million have been hosted by the neighbouring countries and among these countries Turkey has

37 Avrupa Birliği Konsey Kararı 2001/235/AT. Ministry of the EU, Republic of Turkey. Accessed: August 12, 2021, https://www.ab.gov.tr/files/AB_Iliskileri/AdaylikSureci/ Kob/Turkiye_Kat_Ort_Belg_2001.pdf 
been hosting the largest number of refugees with more than 3,6 million registered ones. ${ }^{38}$ While Turkey has been bearing the brunt of the refugee crisis most since the very first day, in this process, the importance of Turkey's geopolitical position in terms of EU's border security became more evident.

The efforts of irregular migrants, Syrians and other refugees in Turkey to go to Europe through Greece after April 2011, in fact, demonstrated dramatically how important the EU-Turkey cooperation was. Between 2014 and 2016, more than 1 million refugees or irregular immigrants half of whom were Syrians reached Greece via Turkey. ${ }^{39}$ It was a shocking mass migration crisis for Europe and in order to keep the immigrants out of its borders, EU agreed on a Statement on March 18, 2016 with Turkey who had long been waiting for the revival of membership negotiations and visa liberalization until then, making Turkey a buffer zone for immigrants. ${ }^{40}$ Ever since the refugee crisis started knocking on its borders, the EU started to have some disagreements within itself, and when it got to the point where the Dublin Convention was no longer working, it decided that it would be a better policy to resolve the refugee issue before it reached its own territory. Thus began the process of alienating the refugee crisis from its own borders by externalizing it rather than trying to solve it at the lands it arouse. After the EU-Turkey Statement, though the number slowed down radically as it was agreed upon (a total of 150 people elapsed between April 2016 and December 2019), it became obvious that this process is likely to continue due to ongoing instability in the region and increasing number of asylum seeker and irregular migrant stock in Turkey where the numbers have already exceeded 5 millions. ${ }^{41}$

Although EU-Turkey reconciliation, a typical "externalizing" policy example, led to extremely positive results in terms of the fall in the number

38 The UN Refugee Agency. "Syria Emergency - 2021.” Accessed: September 19, 2021, https://www.unhcr.org/syria-emergency.html

39 DGMM. "2016 Türkiye Göç Raporu”. Turkish Ministry of Interior - Directorate General for Migration Management. Accessed: August 14, 2021, https://www.goc.gov.tr/ kurumlar/goc.gov.tr/YillikGocRaporlari/2016_yiik_goc_raporu_haziran.pdf

40 Zuhal Karakoç Dora, "Turkey-EU Relations in Context of Syrian Crisis: Readmission Agreement and Visa Liberalisation." MAKU Sosyal Bilimler Enstitüsü Dergisi, No 32 (2020) : 102.

41 For updated numbers see https://www.goc.gov.tr/duzensiz-goc-istatistikler (DGMM, 2021). 
of migrants trying to reach the territories of the EU, the management of the process and the reduction in serious costs; it is possible to claim that it was not satisfactory enough due to the failure both in the application of the political promises given to Turkey in the agreement (visa liberalisation) and resettlement of the refugees to the states in the EU. Though it has been the largest financial external support on migration issues received by Turkey ${ }^{42}$, it is clear that a new consensus is needed between Turkey, who takes the economic, financial, social and political risks and faces with continually increasing number of migrants, and the EU.

The Syrian refugee crisis has been an important test in the border and immigration policy that the EU has tried to manage with Schengen since 1984 and FRONTEX since 2004. This has been a subject of both cooperation and voltage between the EU and Turkey each passing day. Upon martyrdom of the Turkish troops in Idlib in February 2020, Turkey announced that the refugees wishing to go to Europe shall not be stopped which caused a major mobility on the borders. Although it was somehow interrupted due to COVID-19, there were border crossings from Turkey towards EU territories through Greece which, in the end, led European leaders to make speeches on further cooperation with Turkey for border policies and forced Greece to strengthen its border security with armed forces and more barbed wires. In this context, statements from the EU were extremely interesting. EU Commission President Ursula von der Leyen, in her visit to Greece-Turkey border on March, 3, gave support to the harsh attitudes towards immigrants in Athens border. Visiting the Kastanies (Kestanelik) Border Gate across the Pazarkule Border Gate, von der Leyen said "This border is not only a Greek border, this is also a European border". ${ }^{43}$ In fact, this statement gives extremely important clues in terms of understanding the EU's border and border protection logic. Turkey's loosening of the controls at the border gate opened to Europe via Greece, after some disagreements with the EU, had not yet found sufficient repercussions and the ground for discussion or reconciliation when the COVID-19 pandemic broke out. For the EU, which had already hardened its border security policies against the influx of refugees, the pandemic brought

42 Delegation of the EU to Turkey, "EU Funded Projects in Turkey." 2021, Accessed: November 5, 2021, https://www.avrupa.info.tr/en/eu-funded-projects-in-turkey

43 Deutsche Welle, “AB'den Yunanistan'a Tam Destek.” 2020, Accessed: August 14, 2021, https://www.dw.com/tr/abden-yunanistana-tam-destek/a-52627368 
with the opportunity for new and more stringent security measures and an important argument for border closure, which should be considered as a natural reaction of every government trying to protect the health and life of its citizens against the virus that may come from outside.

\section{A New Approach to the Concept of Border during Covid-19 Pandemic}

While protecting the state itself was the most important goal in the past, and sometimes the way to do this is to sacrifice people for this purpose; today, where the value of human life and quality living in prosperity come to the fore, the way to protect the state is to protect the individual and society. With the emergence of new security threats; borders have become a means of "protecting people and their possessions", not against other states, but against uncontrollable humanitarian movements or non-state actors and the terrorist organizations.

With each passing day, many policies and control systems of the civilized world, such as visas, have become vital for the protection of not only land but also air and sea borders. With COVID-19 a new area of border protection has come to the scene that had not been witnessed before. Border security gained a different meaning when the World Health Organization declared COVID-19 as "pandemic" on March 11, 2020. Before March 11, it was seen that the humanitarian mobility originating from China was tried to be controlled, and then the centre of the epidemic spread to Europe, especially Italy, and EU member countries, which had been boasting of removing the borders between themselves, had to take strict measures against each other. While the number of deaths from COVID-19 in Italy was only 3, the train departing from Italy, an EU member, was stopped from entering Austria, another EU member and neighbouring country, on February 23, 2020. On February 24, all train services were stopped. ${ }^{44}$ In the three weeks that passed until March 11, measures began to be prepared all over the world. However, it was seen that these measures were taken within the EU, especially considering Italy where the crisis grew. After the pandemic was announced, almost all countries closed their borders hastily.

44 Anatolian Agency, “Avusturya Covid-19 Salgını Nedeniyle İtalya'dan Tren Seferlerini Durdurdu." 2020, Accessed: August 16, 2021, https://www.aa.com.tr/tr/dunya/avusturyakovid-19-salgini-nedeniyle-italyadan-tren-seferlerini-durdurdu/1742728 
Over time, although these measures were increased and relaxed according to the increase and decrease in the speed of the pandemic in places, despite the intervening two years, many measures began to become permanent and have been tightened. Countries have begun to impose different restrictions on each other according to each other's health system, treatment method and/or the number of cases, and while applying these restrictions, they have started to ignore the basic principles of the EU such as human rights or freedom of movement.

In modern times, borders have been closed for the first time and the argument has been the security of people living within those borders. According to securitization theory of Buzan, any kind of issue today might be turned into a security problem by political discourse which does not mean that it is a real threat. ${ }^{45}$ Presenting as "security issue" of any problem leads to ignore alternative solutions other than the military ones and makes it difficult to resolve the threats faced by societies; at this point "national security" becomes primary target and security needs of the individual and society fall into a secondary position vis-à-vis national security or is completely ignored. ${ }^{46}$ In this context, COVID19 offered states a unique opportunity and paved them the way for taking extreme measures by securitizing the issue. By securitizing the issue of COVID-19, the transitions of countries from rule of law to partial police state are reasonably justified because the establishment of the safety of the people is the first priority of the states, and for this reason, controlling fundamental rights and freedoms by going beyond the law at times could be considered reasonable in such extraordinary situations.

\section{Closed Borders to the Unvaccinated Ones}

It is expected that the size of the fear and anxiety in the societies about securitization will be in direct proportion to the size of the threat expressed and shown. The COVID-19 outbreak has, thus, opened up another field for discussions on why "society" and "state" exist, where it gets its power, and what the limits are. The state of social demand, which encourages the state to take many measures, including curfews that directly violate individual

45 Barry Buzan et al., Security: A New Framework of Analysis. (Boulder: Lynne Rienner Publishers, 1998), 25-32.

46 A. Şevket Ovalı, "Ütopya ile Pratik Arasında: Uluslararası İlişkilerde İnsan Güvenliği Kavramsallaştırması", UI Dergisi, Volume 3, No, 10 (2006): 3-7. 
freedom, in a very passive attitude in order to prevent the anxiety and panic of the society and to stop the epidemic, in fact, showed how fragile the perception of freedom-threat is. This balance has legitimized a much harsher attitude to the threat perception from outside the country. Persons from other countries where the measures were not applied in the same way could, therefore, pose a significant threat.

Some countries first introduced entry restrictions for citizens of other countries where the number of cases was trending upwards. Later, this situation began to turn into a policy of mutual retaliation and countries began to use flight bans and border closures as leverage against each other. These restrictions, which have started to turn into an economic sanction of countries against each other especially during tourism periods, have also evolved into a tool that prepared the ground for drastic policy changes, notably in refugee and immigrant policies. A different dimension has been brought to global competition as countries have started to impose restrictions on each other not only in border policies for individuals, but also in import and export policies, that is, on products crossing the borders, only on the grounds of pandemic.

Vaccines, developed in several countries at around the same time, when the anxiety was worldwide high, took the pandemic and restrictions to a new dimension. The first and one of the ongoing discussion was that although all phases of the vaccines were not completed and the possible side effects were not fully known, some of them have received emergency use approval from the WHO and some countries imposed these vaccines on their citizens and made it mandatory for those who would come to their countries. Although vaccination is an individual choice, depriving individuals of many fundamental rights if they are not shot is illuminating in terms of the point of securitization policies, but frightening in terms of the future.

Another controversial aspect of the issue is the obligation to declare personal data. Today, in many countries, it has become mandatory to present many personal health data, from vaccination status to test status, in public spaces where the simplest daily needs are met. In the same way, criteria such as the obligation to have negative results from the tests at border crossings, the obligation to have at least two doses of the vaccines in the vaccine list preferred by the country of entry have been introduced. 
Another debate regarding to vaccination issue is the possibility to request a "vaccine passport" from border crossers of which stereotype -a mobile application showing/confirming that person have had a COVID vaccine- is already in use at some borders, like the UK. ${ }^{47}$ Such applications show the vaccination and testing data beside facilitating the person's tracking by the state. The fact that this issue is now associated with the concept of "passport" explains how the content of the concept has changed. The passport is a document containing the identity information of the person, but now there is a possibility of additional requirement for personal health data and even not being taken into the country if not vaccinated. The first part of a vaccination passport is the user's official or approved electronic immunization record and today; the European Union, China and Japan are all working on their own digital vaccination certificates for cross-border travel which make people question about privacy and vaccine inequality linger. ${ }^{48}$ This issue is highly controversial from the perspective of violation of personal rights as it has a wide range of options and imperative possibilities from those who want to be vaccinated but cannot access the vaccine -like refugees and irregular migrants- to those who do not want to be vaccinated.

\section{Conclusion}

\section{A Future Perspective: What is Ahead in the Period of Post-covid-19?}

While the world is becoming increasingly integrated and "borderless" where national barriers against the movement of commodities and capital are progressively being abolished; the governments, on the other hand, are forcing the limits to reinforce their frontiers with physical barriers, new technologies and personnel to restrict the movement of unwanted people. ${ }^{49}$

47 See Tariro Mzizewa, "Coming Soon: the Vaccine Passport", https://www.nytimes.com/ 2021/02/04/travel/coronavirus-vaccine-passports.html and "What is a Covis Passport and What are the Plans for the NHS App?", 19 May 2021, Accessed: August 29, 2021, https://www.bbc.com/news/explainers-55718553

48 Kelvin Chan, "What to know about the vaccine passports already being tested for international travel." 2021, Accessed: August, 30, 2021, https://www.usatoday.com/ story/travel/news/2021/05/26/covid-vaccine-passport-international-travel-vaccineproof $/ 7444454002 /$

49 Matt Carr, "Beyond the Border." Accessed: August 16, 2021, https://www.historytoday.com/ archive/history-matters/beyond-border 
As mentioned above, the question of "whose security" is traditionally answered as the "state" by realists -traditionalists-; and from the viewpoint of extended security supporters its answer is "individuals and communities". According to this approach, should the individuals and communities are not secured, then the state is not secured as well. Since the very beginning of history, the security has been top priority in the agendas of the states and until the end of the Cold War, when new security threats are accepted as serious as the military ones, the security issue was very much linked with hard military measures which included rough border policies. After the Cold War, with the effect of globalization, the policy of removing the borders and introducing "borderlessness" to the world in a wide range was led by the EU. However, as time went on, the emergence of new threats led to a gradual departure from these policies. The refugee crisis was a milestone in this sense and it was followed and solidified by COVID-19 pandemic.

Until very recently, while the issue of Syrian refugees has been treated as a security issue and there have been serious discussions and conflicts over it, COVID-19 carried the issue of border security to a new dimension that never came to mind. With COVID-19, the world seems to have entered a new period with long effects. It is understood that one of the issues that will be most affected in this process is the border security area. It seems that the restrictions to be made taking the public health into account will probably receive great support from the society; thus, the governments of many countries throughout Europe seems to consider this process as a way to close the borders, take further security measures, increase the number of requested document through border crossings which might lead to a proportional decrease in the right of free mobility and the efficiency of the international law.

Despite the development of different types of vaccines as of April 2021, the supply of the vaccines and vaccination of people are not up to the mark yet. Steps towards normalization are expected to be taken but it is likely that new Coronavirus species appear in certain periods with new waves or worse mutations. However, in any case, the process in COVID-19 pandemic has added a new dimension to border controls and security. This dimension includes measures such as providing health documents, fever checks, test results and/or vaccination status before visa or travels. Now it seems that 
countries will not only protect their borders from weapons, soldiers, irregular migrants or terrorists, but also against the spread of diseases.

Undoubtedly, in a globalizing and shrinking world, circulation is getting harder day by day, and the measures are getting tougher rather than looser, which cannot be explained by simple security measures alone. Hence, the underlying reasons for security policies should be thoroughly examined. Understanding that the "self" protection motive against the "other" has started to dominate in a world where welfare and supply are shrinking while population is constantly increasing, will contribute to explain the change in security and border policies. Securitization of the issue will help removing "others" (other than the citizens) out of the plans of the states as new measures have easy-access for the insiders while too hard for the outsiders. It seems that the fight against the refugee influx, which is defined as the most serious threat faced by EU countries especially after Syrian civil war, will continue in a more comprehensive and health-based manner, possibly with COVID-19 pandemic. There might be brand new measures on the way to be brought to the agenda. In this respect, it could be argued that COVID-19 pandemic has prepared a legitimate ground to further increase the border security measures which have already been tightened by uncontrolled migration wave. With the help of new arguments such as protecting public health, it enabled the EU to set more selective criteria for border crossings (like vaccine passport) and thus strengthened the justification of harsh border policies it implements against the refugee problem, which has high social and political costs. 


\section{References}

Akkaya, Adem. "Almanya'nın Zorunlu Tercihi: Mülteci Krizi Ekseninde Türk-Alman Ilişkilerini Yeniden Düşünmek,” Regional Studies 1, no 1 (2016): 23-49.

Anatolian Agency, "Avusturya Covid-19 Salgını Nedeniyle İtalya'dan Tren Seferlerini Durdurdu", 2020, Accessed: August 16, 2021, https://www.aa.com.tr/tr/dunya/avusturya-kovid-19-salgini-nedeniyle-italyadantren- seferlerini-durdurdu/1742728.

Avrupa Birliği Konsey Kararı, 2001/235/AT, Ministry of the EU, Republic of Turkey, Accessed: August 12, 2021, https://www.ab.gov.tr/files/ AB_Iliskileri/AdaylikSureci/Kob/Turkiye_Kat_Ort_Belg_2001.pdf.

Aydin, Mustafa et al., Strateji ve Güvenlik. Eskişehir: Açıköğretim Fakültesi Yayınları, 2012.

Baldwin, David, “The Concept of Security," Review of International Studies 23, no1 (1997): 5-26.

Blake, Michael, "What Exactly Is the Point of the Border?," 25 July 2018, Accessed: August 12, 2021, https://theconversation.com/what-exactly-is-thepoint-of-the-border-99990.

Blanton, Shannon Lindsey and Charles William Kegley, World Politics: Trend and Transformation. Boston: Wadsworth: Cengage Learning, 2016-2017.

Brooks, Christopher, "Western Civilization: A Concise History Volume 3: Religious Wars", 2019, Accessed: August 14, 2021, https://pressbooks.nscc.ca/ worldhistory/front-matter/174/.

Buzan, Barry, People, States and Fear: An Agenda for International Security Studies in the Post-Cold War. London: Pearson Longman, 1991.

Buzan, Barry et al., Security: A New Framework of Analysis. Boulder: Lynne Rienner Publishers, 1998.

Carr, Matt, "Beyond the Border," 2013, Accessed: August 16, 2021, https://www.historytoday.com/archive/history-matters/beyond-border.

Cash, Bill, John Bright: Statesman, Orator, Agitator. New York: I. B. Tauris \& Co Ltd., 2012.

Chan, Kelvin, "What to Know About the Vaccine Passports Already Being Tested for International Travel", 2021, Accessed: August 30, 2021, https://www.usatoday.com/story/travel/news/2021/05/26/covid-vaccinepassport-international-travel-vaccine-proof/7444454002/. 
Cote-Baucher, Karine, Federica Infantino and Mark Salter, "Border security as practice: An agenda for research," Security Dialogue. No 45 (2014): 195-208.

Council of the European Union, "Council Regulation (EC) No:2007/2004," 26 October 2004, Accessed: September 13, 2021, https://eur-lex.europa.eu/ eli/reg/2004/2007/oj.

Council of the European Union, "A Fresh Start on Migration: Building Confidence and Striking a New Balance Between Responsibility and Solidarity," 2020, Accessed: August 30, 2021, ec.europa.eu/commission/presscorner/ detail/en/ip_20_1706.

Council of the European Union, "Temporary Reintroduction of Border Control," 2021, Accessed: August 10, 2021, https://ec.europa.eu/home-affairs/what-we do/policies/borders-and visas/schengen/reintroduction-border-control_en.

Delegation of the EU to Turkey, "EU Funded Projects in Turkey," 2021, Accessed: November 5, 2021, https://www.avrupa.info.tr/en/eu-funded-projects-inturkey.

Deutsche Welle, “AB'den Yunanistan'a Tam Destek,” 2020, Accessed: August 14, 2021, https://www.dw.com/tr/abden-yunanistana-tam-destek/a-52627368.

DGMM, "2016 Türkiye Göç Raporu,” Turkish Ministry of Interior - Directorate General for Migration Management, Accessed: August 14, 2021, https://www.goc.gov.tr/kurumlar/goc.gov.tr/YillikGocRaporlari/2016_yiik_go c_raporu_haziran.pdf.

DGMM, “İstatistikler - Düzensiz Göç - 2021,” Turkish Ministry of Interior Directorate General for Migration Management, Accessed: August 14, 2021, https://www.goc.gov.tr/duzensiz-goc-istatistikler.

Edsall, Nicholas C., Richard Cobden: Independent Radical. Boston: Harvard University Press, 2014.

Erdoğan, M. Murat, "Securitization from Society" and "Social Acceptance": Political Party-Based Approaches in Turkey to Syrian Refugees," UI Dergisi. 17, no 68 (2020): 73-92.

Erdoğan, M. Murat, "Açık Kapı Politikasından Açık Sınır Politikasına Türkiye'deki Suriyeliler," Accessed: August 29, 2021, https://www.uikpanorama.com/blog/ 2020/03/09/acik-kapi-politikasindan-acik-sinir-politikasina-turkiyedekisuriyeliler-murat-erdogan/.

FRONTEX, "Key Facts", 2021, Accessed: September 11, 2021, https://frontex.europa.eu/faq/key-facts/. 
FRONTEX, "Origin and Tasks", 2021, Accessed: September 11, 2021, https://frontex.europa.eu/about-frontex/origin-tasks/.

Hollifield, James F., "The Emerging Migration State," The International Migration Review. 38, no 3 (2004): 885-912.

Hugo, Victor, "Speech of Victor Hugo to the Peace Congress at Paris", The Sydney Morning Herald, December 26, 1849.

International Organization for Migration, "Compilation of Available Data and Information - 2015," Accessed: September 11, 2021, https://www.iom.int/ sites/default/files/situation_reports/file/Mixed-Flows-Mediterranean-and-

Beyond-Compilation-Overview-2015.pdf.

Kant, Immanuel, "Perpetual Peace," In: Reiss, H. (ed.) Kant's Political Writings, Cambridge: Cambridge University Press, 1970.

Karakoç Dora, Zuhal, "International Migrants as a Matter of Security: Open Door Policy and Syrians in Turkey," Güvenlik Bilimleri Dergisi - Journal of Security. 9, no 2 (2020): 501-524.

Karakoç Dora, Zuhal, "Turkey-EU Relations in Context of Syrian Crisis: Readmission Agreement and Visa Liberalisation," MAKU Sosyal Bilimler Enstitüsü Dergisi. No 32 (2020): 100-112

Karakoç Dora, Zuhal, "Borders, Terror and Immigration: the ISIS Case," in Securites Issues in the Context of Political Violence and Terrorism of the 21st Century, Eds. Hasan

Kirişçi, Kemal et al., "The EU's New Pact on Migration and Asylum is Missing a True Foundation," 2020, Accessed: August 30, 2021, https://www.brookings.edu/blog/order-from-chaos/2020/11/06/the-eus-newpact-on-migration-and-asylum-is-missing-a-true-foundation/.

Lodewyckx, Ina et al., "From Nation State to Migration State," Economics and Sociology. 3, no 2 (2010): 9-22.

Loescher, Gil, The UNHCR and World Politics: A Perilous Path. Oxford: Oxford University Press, 2001.

Maslow, Abraham H., "A Theory of Human Motivation," Physiological Review. 50, no 4 (1943): 370-396.

Miles, Tom and Mariana Depetris, "October's Migrant, Refugee Flow to Europe Roughly Matched Whole of 2014", Reuters UK, November 2, 2015, Accessed July 30, 2021, https://www.reuters.com/article/us-europe-migrants-un/ 
octobers-migrant-refugee-flow-to-europe-roughly-matched-whole-of-2014idUSKCNOSR15P20151102.

Mill, John Stuart, Principles of Political Economy with Some of Their Applications to Social Philosophy. 1st Ed. London: John W. Parker, 1848.

O'Dowd, Liam, "From a 'Borderless World' to a 'World of Borders: Bringing History Back In,” Society and Space, no 28 (2010): 1031-1050.

Ovalı, A. Şevket, "Ütopya ile Pratik Arasında: Uluslararası İlişskilerde İnsan Güvenliği Kavramsallaştırması," UI Dergisi, 3, no 19 (2006): 3-52.

Ricardo, David, On the Principles of Political Economy and Taxation. London: John Murray, 1817.

Sevastianov, Sergei V., Jussi P. Laine, and Anton A. Kireev, Introduction to Border Studies. Vladivostok: Dalnauka, 2015.

Tibken, Shara and Joan E. Solsman, "For Refugees on Hungary's Border, Razor Wire Trumps Tech,” 2016, Accessed: August 17, 2021, https://www.cnet.com/news/for-refugees-on-hungary-serbia-border-razor-fencewire-trumps-tech/.

Ullman, Richard H., "Redefining Security,” International Security. 8, no 1 (1983): 129-153.

United Nations, "Post-war Reconstruction and Development in the Golden Age of Capitalism," World Economic and Social Survey 2017, Accessed: August 17, 2021, https://www.un.org/development/desa/dpad/wp-content/uploads/sites/ 45/WESS_2017_ch2.pdf.

UN Refugee Agency, “Syria Emergency - 2021,” Accessed: September 19, 2021, https://www.unhcr.org/syria-emergency.html.

Urker, Ertuğrul, "COVID-19: The Virus Crossing Borders," 2020, Accessed: August 25, 2021, https://www.internationalaffairshouse.org/covid-19-thevirus-crossing-borders/.

Walt, Stephen M., "The Renaissance of Security Studies," International Studies Quarterly. 35, no 2 (1991): 211-229.

Zupancic, Jernej, "The European Refugee and Migrant Crisis and Slovenian Response," European Journal of Geopolitics. No 4 (2016): 95-121. 
